\title{
Katherine Mansfield and Anima Mundi: France and the Tradition of Nature Personified
}

\author{
Janet Wilson
}

\begin{abstract}
This chapter proposes a speculative reading of Katherine Mansfield's work in relation to the medieval concept of anima mundi (world soul), that is, the belief in an animistic universe in which the earth is revivified through a spiritus mundi (spirit of the world). Although no explicit link can be made, I suggest that Mansfield had affinities with medieval cosmology which fostered a more participatory relationship between the human subject and the created world than the post-Cartesian world view does. I also suggest that this relationship between the self and the 'other' is often marked by a 'decentring' modernist aesthetic that enables her to represent it as odd, disturbing or disruptive. The first section of this chapter identifies central concepts associated with the belief in anima mundi, as found in the writings of the French philosophers, writers and artists of the twelfth and thirteenth centuries. This is followed by a discussion of three motifs associated with the tradition of nature personified that survived into modernist culture with reference to particular stories in which Mansfield seemingly rewrites them into a contemporary idiom.
\end{abstract}

\section{Anima mundi and spiritus mundi}

The concept of anima mundi, that nature is a living creature of both organic and sentient species, associated with a mystique of participation and sense of reciprocity between all living things, comes from the Greek theoretician, Pythagoras. The doctrine and Pythagorean cosmology also insist on spiritus mundi, the presence of the soul in the order of nature. Nature alone rules the cosmos and is deserving of the worship usually directed at gods.

From the third and fourth centuries A.D. Nature appears in Orphic hymns, represented as a cosmic power and a universal goddess who has power over man's soul and governs marriage and the generation of the species because of her inexhaustible vitality. ${ }^{1}$ Her complaint about mankind (mainly on the grounds of his sexual license) allows her to intervene in human history. Like the god Pan she resembles one of the last pagan gods who survives into Christian thinking, although these classical representations are often at odds with Christian belief. Even in the work of later medieval writers like Bernard de Silvestris and Alan of Lille, the pantheistic overtones in the veneration of nature (as spiritus mundi) are often linked to paganism. Nature personified is considered as being outside the religious philosophical tradition of Christianity.

The ideas of Pythagoras and the poetry of the Orphists received fuller exploration in the twelfthcentury Renaissance, in which nature was apotheosised through allegories of her in human form: for example, as God's humble pupil, as intermediary between God and man, or as traveller through the heavens bringing form to chaos. These appear in the work of the French pagan humanist, Bernard de Sylvestris of Tours (De Universitate Mundi), the tracts of Alanus de Insulis (Alan of Lille) - his De Planctu Naturae (1170) and Anticlaudianus (c.1185) - and in the continuation of Guillaume de Lorris's thirteenth-century allegorical French poem, Le Roman de la Rose (1230), by the priest Jean de Meun (c.1275), where Dame Nature is imaged as responsible for forging the human race.

A distinctive iconographic tradition developed round these images and persisted in manuscript and print into the sixteenth century. ${ }^{2}$ The visual allegories of the twelfth-century Renaissance in which Nature appears as queenly and crowned, robed in a gown made up of birds, flowers, herbs, beasts and fishes, was an influence on Chaucer and Spenser. Among the illustrations of Nature in manuscripts of Alan of Lille's De Planctu Naturae are some of her wearing a gown, imprinted with birds, fish, beasts, herbs, trees and flowers that moves and rustles as she does, stirring the creatures into life. This anthropomorphic yet artificial fantasy of nature as combining numerous species together in a vast ecological tapestry suggests the mystery and splendour of the natural world; but other illustrations of her robe as torn and stained indicate her vulnerability

\footnotetext{
${ }^{1}$ See the discussion of nature personified in E. R. Curtius, European Literature and the Latin Middle Ages, tr. William R. Trask (New York: Harper \& Row, 1963), pp. 106-27 (pp. 106-7).

${ }^{2}$ Katherine Park, 'Nature in Person: Medieval and Renaissance Allegories and Emblems', in The Moral Authority of Nature, eds Lorraine Daston and Ferdinand Vidal (Chicago and London: Chicago University Press, 2004), p. 55.
} 
due to the interruption of her toil by human sexual excess. ${ }^{3}$ Although it is unlikely that Mansfield read the French medieval philosophers like Alan of Lille she may have viewed some of the illustrations found in manuscripts of his poems. She may also have seen the illustrated manuscripts of the Roman de la Rose, an enormously popular work throughout the Middle Ages (more than 300 survive), either on one of her visits to Paris or at the British Library in London: ${ }^{4}$ even in the early twentieth century images associated with the work of these authors and the Renaissance writers who were influenced by them had gained iconic status and were treated as part of the cultural heritage by modernist writers. Virginia Woolf for example, presents a modernist version of nature in person represented by her golden tresses, attesting to the survival of the French philosophical and poetic legacy through the compelling force of Shakespeare's imagination:

At every moment Nature signified by some laughing hint like that gold spot which went round the wall - there, there, there, - her determination to show, by brandishing her plumes shaking her tresses, flinging her mantle this way and that, beautifully, always beautifully, and standing up close to breathe through her hollowed hands, Shakespeare's words, her meaning. ${ }^{5}$

Other rhetorical topoi related to the Goddess Natura tradition are also inherited from the classical tradition of landscape: namely the locus amoenus (pleasant place), epitome of the ideal landscape in which nature habitually dwells, and other forms of the earthly paradise as found in Alan of Lille's Anticlaudianus. The locus amoenus was the antecedent of the garden of love or the hortus conclusis, the enclosed garden setting found in medieval courtly love lyrics and poems. It was frequently illustrated in French manuscripts of Guillaume de Lorris's allegory, Le Roman de La Rose, a poem that was widely known and read in France; Mansfield's handling in several sketches and stories of the ironies and contradictions of love in a confined space, suggests some familiarity with the courtly love tradition which his poem popularised in the Middle Ages and the Renaissance. There is also the wild space associated with the mixed forest or grove, subject of 'bravura interludes' by Ovid, and later adopted by Chaucer, Spenser and Keats. E. R. Curtius, in his discussion of the Latin rhetorical traditions from pagan antiquity that continued into the Middle Ages, does not mention the sacred tree from pre-Christian pagan societies. Yet beliefs in the cosmological and spiritual truths of trees, identifying them as imago mundi (image of the world), axiomatically linked them to Dame Nature as anima mundi. ${ }^{6}$ An important part of nature, whether as an individual tree or as a wooded grove of different trees, the sacred tree was, like Dame Nature, transformed by the encounter between paganism and Christianity, a tension which Mansfield reads in terms of the sacred and profane.

Mansfield's awareness of the tradition of nature personified may also have been informed by her reading of the poets of the English Renaissance who appropriated it for the pastoral tradition, notably Sir Philip Sidney's Arcadia, Spenser's Faerie Queene and the Mutability Cantos, and the works of Shakespeare. ${ }^{7}$ In particular, Spenser's representation of nature in the Mutability Cantos as full of contradictions and embodying the processes of mutability, a principle of radical instability due to the forces of change, death and destruction, may have been an influence; certainly Spenser's innovative treatment of this topos can be positioned as transitional between medieval and modernist constructions. ${ }^{8}$ The Renaissance pastoral developed a strong orientation towards and celebration of nature, and encouraged a vision of human subjectivity rooted in nonhuman nature and of humans as being dependent on the natural environment for survival. This was for long a marginalised alternative to the seventeenth-century Cartesian tradition, which elevated human enlightenment and reason above nature and the environment.

The belief that a spiritual energy infused organic life on earth, therefore, together with the pastoral ideal of a responsive, animate landscape, are starting points for examining Mansfield's arcadian, pastoral orientation, manifested in her empathy with living creatures, flowers, plants and trees which she saw as vital

\footnotetext{
${ }^{3}$ Todd A. Borlik, Ecocriticism and Early Modern English Literature: Green Pastures (London: Routledge, 2011), pp. 40-57; see also Park, pp. 54-6.

${ }_{4}$ The most recent survey of extant manuscripts or fragments of Le Roman de la Rose records over 100 held in the Archives Nationale or the Bibliotheque de l'Institut de France, both in Paris, by far the greatest number anywhere in the world. See 'Roman de la Rose Digital Library'.

https://docs.google.com/spreadsheet/ccc?key=0AsygG3xkhMdcHFwWTFJVIZCeS1BM0FMZ0F6ZVBSU0E\#gid=0 (accessed 1 December 2014).

${ }^{5}$ Virginia Woolf, Mrs Dalloway (Harmondsworth: Penguin [1925] 1996), p. 154.

${ }^{6}$ Carole M. Cusack, The Sacred Tree: Ancient and Medieval Manifestations (Newcastle-upon-Tyne: Cambridge Scholars Publishing, 2011), pp. xiv-xv.

${ }^{7}$ Mansfield's reading of Chaucer, Spenser and Shakespeare is attested in her letters and notebooks.

${ }^{8}$ Richard Chamberlain, Radical Spenser: Pastoral, Politics and the New Aestheticism (Edinburgh: Edinburgh University Press, 2005), pp. 125-6. The medieval writers saw Nature as enigmatic, concealing her true form beneath her garments; see Park, p. 71; similarly Spenser imaged nature as being veiled and either inaccessible or mediated. Both would have appealed to Mansfield's aesthetics of the veil and the glimpse as filters of reality.
} 
forces with independent lives. The sense of wonder and marvel at the created world in response to its mystery and splendour, often noted in her work, are arguably traceable to anthropomorphic attitudes that originated with the French allegories of Dame Nature of the twelfth and thirteenth centuries. ${ }^{9}$ Embracing the pantheistic powers of the natural world aligns her with fellow modernists like D. H. Lawrence, E. M. Forster, and Virginia Woolf. Yet in her modernist appraisal, the impulse towards a wholistic surrender to a natural pantheistic order as found in stories with settings based on the locus amoenus and the rooted tree often carries negative overtones of denial or betrayal, just as enjoyment of the cultivated, leisure garden involves irony and self-questioning.

To Mansfield, images of organic growth and spiritual forces - one legacy of the tradition of Dame Nature's mediation between god and man - invite celebration and delight although the threat of illusion, deception and erosion of selfhood always hovers. Such ambivalence may be read as a form of resistance to and reinterpretation of the essentialist constructions of gender that underpin the tradition of nature personified (transmitted through patriarchal, authoritarian figures like Alan of Lille and the Italian Renaissance humanists). Dame Nature was associated with biological metaphors and images of generation and reproduction that dominate bodily processes and the unconscious in works like Jeun de Meun's continuation of Le Roman de la Rose, where she hammers out new human beings in order to outstrip death and in the visual tradition of the sixteenth century Italian humanists which represents her as a naked lactating woman endowed with many breasts. ${ }^{10}$ Representations like these would have clashed with Mansfield's modernist belief in art's power to order, and her use of parody, ironic distance and fragmented and discontinuous narrative, to undermine and interrupt the veneration of natural powers and elemental forces. ${ }^{11}$

Three major topics can be identified in Mansfield's engagement with the cultural heritage of the anima mundi concept:

1. The god Pan or pantheism, a form of nature worship which recalls the medieval goddess Natura and the agency of objects.

2. The locus amoenus or pleasant place (which began with the classical tradition as the hortus conclusis and came into the medieval world as the enclosed garden of courtly love) and the grove or wilderness. 3. Trees as both axis mundi (axis of the world) and imago mundi (image of the world) and the trope of the arboreal epiphany.

\section{The god Pan}

That Mansfield was keenly aware of contemporary views about pantheism - a form of nature worship appears in scattered comments about the god Pan (the half-goat, half-man, Greek god of shepherds, flocks and music in Arcadia) who was then in vogue among writers and naturalists. She wrote a review of The Triumph of Pan, a volume of poetry by Victor Neuberg, an occultist and associate of Aleister Crowley, whom Mansfield once smoked hashish with in her experimental phase, and she also dedicated to the deity an early (1908) poem: 'To Pan', celebrates the continuing power of Pan, 'the munificent giver' over human lovers, as he '[f]ashioned the song of our firebound heart', although significantly the beloved (addressed as 'you' in the poem) alleges that the narrator's sensations bear the stigma of a 'subjective passion'. ${ }^{12}$

Mansfield's question, 'Do you believe in Pan?' on first meeting the young writer William Orton, suggests the name Pan was a code for an instant sexual attraction. ${ }^{13}$ This phrase is repeated in the story 'Epilogue II', in which the narrator's friend, Violet Burton, tells her about falling in love with a man she believes to be a kindred spirit. ${ }^{14}$ Their shared belief in Pan gives him instant access to her soul, and it becomes conflated with Pan's associations with sexuality in their exchange, leading to a kiss.

\footnotetext{
We danced together seven times and we talked the whole time [...] we talked of everything. You know ... about books and theatres and all that sort of thing at first, and then - about our souls'.$$
\text { '.... What?' }
$$

9 See Anne Mounic, “'Ah, What is it? - that I Heard”: The Sense of Wonder in Katherine Mansfield's Stories and Poems', in Celebrating Katherine Mansfield: A Centenary Volume of Essays, eds Gerri Kimber and Janet Wilson (London: Palgrave, 2011), pp. 14457.

${ }^{10}$ Park, pp. 55-8.

${ }^{11}$ Sydney Janet Kaplan, Katherine Mansfield and the Origins of Modernist Fiction (Ithaca and London: Cornell University Press, 1991), p. 65.

12 Both texts are reprinted in Gerri Kimber, Gerri and Angela Smith, eds, The Edinburgh Edition of the Collected Works of Katherine Mansfield, Vol. 3 (Edinburgh: Edinburgh University Press, 2014), pp. 430-1, pp. 60-1. The review was first published in Rhythm, 2 (July 1912), p. 70.

${ }_{13}$ William Orton, The Last Romantic (London: Cassell, 1937), pp. 269-70.

14 Written in c.1913, 'Epilogue II’ was published by John Middleton Murry as 'Violet'.
} 
'I said - our souls. He understood me absolutely [...] I must tell you the first thing he ever said to me. He said, 'Do you believe in Pan?' Quite quietly. Just like that. And then he said, 'I knew you did'. [...]. And ... shall I go on?' 'Yes, go on.'

'He said, 'I think I must be mad. I want to kiss you' - and - I let him'.15

Mansfield's critique of romantic love, and ironic deflation of the narrator's expectation of a story that will satisfy her craving for romance, is reflected in the location of this encounter: an idealised garden setting that recalls the hortus conclusus in which medieval scenes of courtly love were rehearsed, sealed off from reality. The little garden on the opposite side of Rue St Leger in Geneva where the narrator is staying is unnaturally perfect: 'Although autumn was well advanced, not a leaf had fallen from the trees, the little shrubs and bushes were touched with pink and crimson, and against the blue sky the trees stood sheathed in gold' $(C W 1,332)-$ just like the non-seasonal, artificial setting of the hortus conclusus. Yet this idyllic setting is undermined by human connotations in the play of water: the nearby fountain sounds to the narrator 'like a half-forgotten tune, half sly, half laughing'. To Violet, though, it is 'Like weeping in the night' - appropriately - for the story she tells is one of betrayal in love (CWI, 333). The narrator concludes with a pathetic fallacy: the fountain's laughter seems to mock her desire for a more scandalous story. ${ }^{16}$

\section{IMAGE OF FOUNTAIN AND GARDEN OF PLEASURE}

By contrast to these veiled allusions to Pan as either a benevolent or treacherous love deity, Mansfield's contemporaries turned to paganism and the god Pan to urge a closer link with nature and to critique modern technology. E. M. Forster's story, 'The Story of Panic' (1911), turns on nature's regenerative potential for mankind, while a more explicit statement about nature's powers comes from D. H. Lawrence in 'Remembering Pan'. ${ }^{17}$ Lawrence sees nature as a 'repressed force, a forgotten deity', 18 and Pan as a priapic demonic creature, a 'lurking rustic god with a goat's white lightening in his eyes', more like a demon than a god. ${ }^{19}$ Humans to Lawrence were part of the biosphere and did not have superior status to other living beings. In urging man's union with nature he implies modernism's repudiation of mechanisation and a concern for the environment:

The Pan relationship, which the world of man once had with all the world, was better than anything man has now [...]. Because, when all is said and done, life itself consists in a live relatedness between man and his universe: sun, moon, stars, earth, trees, flowers, birds, animals, men, everything - and not in a 'conquest' of anything by anything. [...].

And whether we are a store clerk or a bus conductor, we can still choose between the living universe of Pan. and the mechanical conquered universe of humanity. ${ }^{20}$

Lawrence's attitude recalls the manifestos on modernist art published in 1911, in the first issue of the avant garde magazine, Rhythm, that urged reaching towards a deeper sense of self and familiarisation with our 'outcast selves'. ${ }^{21}$ Rhythm's editors aimed to provide an art that would have 'its roots below the surface, and be the rhythmical echo of the life with which it is in touch';22 for art, according to John Middleton Murry, 'penetrates beneath the outward surface of the world, and disengages the rhythms that lie at the heart of things, rhythms strange to the eye, unaccustomed to the ear, primitive harmonies of the world that is and lives'.23

\section{The Locus Amoenus}

Mansfield's animistic view of reality as anthropomorphic and vitalistic stems from her potential for transitivity, for crossing over from the self to the other; this is due to her sense of intimacy with nature and identification

\footnotetext{
15 Gerri Kimber and Vincent O'Sullivan, eds, The Edinburgh Edition of the Collected Works of Katherine Mansfield, Vols 1 and 2 (Edinburgh: Edinburgh University Press, 2012), Vol. 1, p. 355. Hereafter referred to as CW, followed by volume and page number.

16 W. H. New, Reading Mansfield and Metaphors of Form (Montreal \& Kingston, McGill-Queen's University Press, 1999$)$, p 144.

17 See Maurizio Ascari, 'Katherine Mansfield and the Gardens of the Soul', Katherine Mansfield Studies, 2 (2010), pp. 47-8.

18 Laurence Coupe, 'Introduction' to Part II of The Green Studies Reader: From Romanticism to Eco-Criticism, ed. Laurence Coupe (London: Routledge, 2000), p. 62.

${ }^{19}$ D.H. Lawrence, 'Remembering Pan', in Coupe, p. 70. The text was first published posthumously in 1936 as part of 'Pan in America'.

20 Lawrence, 'Remembering Pan', in Coupe, p. 72.

${ }^{21}$ Frederick Goodyear, 'The New Thelema', Rhythm 1.1 (1911), p. $3 .$.

22 Anon., 'Aims and Ideals', Rhythm, 1: 1 (1911), p. 36.

23 John Middleton Murry, 'Art and Philosophy', Rhythm, 1: 1 (1911), p. 12.
} 
with natural phenomena. Nature is not an external being or force, therefore, but an energy with which she felt in touch. Such empathetic associations appear in all the genres in which she wrote and often propel her towards the fantastic and marvelous, modes which, as Rosemary Jackson says, are dominated by 'an attempt [...] to resist separation and difference, to re-discover the unity between self and other'. ${ }^{24}$ William Orton with whom Mansfield was friendly for a while in 1910, remarked of her symbolism, for example, that it resembles Chekhov's: things are made to speak for themselves, often through the device of prosopopeia. ${ }^{25}$ Inanimate objects seem to come alive, showing a tendency towards motion that amounts to quasi-agency: even if not part of the natural world, the perceptions of the viewer render them life-like. In 'Prelude', Linda Burnell traces a poppy on the wallpaper and 'under her tracing finger the poppy seemed to come alive. She could feel the sticky, silky petals, the stem, hairy like a gooseberry skin, the rough leaf and the tight glazed bud. Things had a habit of coming alive like that'. The sexual connotation of the images springing to life suggests this represents an awakening. But the objects become a society: 'But the strangest part of this coming alive of things was what they did. They listened, they seemed to swell out with some mysterious important content, and when they were full she felt that they smiled. But it was not for her, only, their sly secret smile; they were members of a secret society and they smiled among themselves' $(C W 2,68)$. Linda's imagined community of animated objects can be read as a modernist version of the Pythagorean creed (inherited from Hermes Trismegistus and espoused in hermetic texts such as the Asclepius), in what Todd A. Borlik calls its 'ethical consideration of non-humans', which states: 'There is a community of souls, the souls of the gods commune with the souls of humans, those of humans with souls of unreasoning things' ${ }^{26}$ Reminiscent of 'the great chain of being', this community of fellowship with the created world is her fantasy, one in which Linda does not participate for it has a separate existence.

Such proximity between self and other (involving some transfer of agency from subject to object) is associated with Mansfield's doctrine of impersonality in art: the creative principle which is life is also an animalistic quality in which she participates, and which cannot be separated from art: 'The artist must give himself so utterly to life that no self qua personal self remains'. ${ }^{27}$ The merging of self and object - so taking the direction away from the self - is a moment of increased inwardness, yet paradoxically, as seeing the essential otherness of thing, perceiving what Gerard Manley Hopkins calls its inscape:28

When I write about ducks I swear that I am a white duck with a round eye, floating in a pond fringed with yellow blobs and taking an occasional dart at the other duck with the round eye, which floats upside down beneath me [...]. There follows the moment when you are more duck, more apple or more Natasha than any of these objects could ever possibly be, and so you create them anew. ${ }^{29}$

On the other hand, this identification has consequences for the perspective and point of view, of being both an observer and then part of the scene, so splitting the subject/narrator's viewing position:

I've been this man, been this woman. Ive stood for hours on the Auckland Wharf. Ive been out in the stream waiting to be berthed. Ive been a seagull hovering in the stern and a hotel porter whistling through his teeth. It isn't as though one sits and watches the spectacle. That would be thrilling enough, god knows. But one IS the spectacle, for the time. ${ }^{30}$

This contrast between the narrator as either spectator of a scene or as participant in it can be mapped onto the divisions in nature and landscape that Mansfield observes. Nature cultivated, domestic and picturesque is distinct from nature as wild or primitive. These traditional personifications of the goddess underlie the different psychological states of rapture or engulfment, leading to fear, hesitation or withdrawal. So by contrast to the Pythagorean anima mundi tradition where the garden is a metaphor for the soul, a plant-like entity that blooms from the environment and disintegrates into it, or the courtly love tradition where the enclosed garden is a place for courtship and social and cultural reinforcement, landscapes, gardens and other natural settings are for Mansfield sites of self discovery, for making psychic connections, renewing the soul, but also experiencing spiritual alienation splitting of the inner self, and establishing distance and difference.

\footnotetext{
${ }^{24}$ Rosemary Jackson, Fantasy: The Literature of Subversion (London: Routledge, 1981), p. 52. Quoted by Ascari, p. 52.

25 Orton, p. 271.

${ }^{26}$ From the Asclepius; quoted by Boruk, p. 58 .

27 Vincent O'Sullivan and Margaret Scott, eds. The Collected Letters of Katherine Mansfield, 5 vols (Oxford: Clarendon Press, 1904-

2008), Vol. 4, pp. 180-1. Hereafter referred to as Letters, followed by volume and page number.

${ }^{28}$ Kaplan discusses this in terms of Bergson's intuition: 'the kind of intellectual sympathy by which one places oneself within a object in order to coincide with what is unique in it and consequently inexpressible'. Henri Bergson, An Introduction to Metaphysics, tr. T. E. Hulme (New York; G.P. Putnam's Sons, 1912), p. 7. Quoted in Kaplan, p. 182.

${ }^{29}$ Letters 1, p. 330.

${ }^{30}$ Letters 4, p. 97.
} 
These divisions appear in the early prose piece, 'In the Botanical Gardens' (1907), about the botanical gardens in Wellington, which show 'a subtle combination of the artificial and the natural'. The enclosure where 'the spring flowers are almost too beautiful' $(C W 1,84)$ recalls the artifice of the enclosed garden or bortus conclusus. The narrator is an onlooker or spectator, but after moving beyond the enclosure to the bush, 'silent and splendid', where she encounters the genius loci (the spirit of the place) she becomes part of the scene, identifying with the archaic world as it appears in the present: 'I am old with the age of centuries, strong with the strength of savagery' $(C W 1,85)$. This landscape is equivalent to the classical locus amoenus which, according to E. R. Curtius, 'is a beautiful, shaded, natural site' with one or more trees, a meadow, spring or brook, and possibly including birdsong, flowers and a breeze. ${ }^{31}$ Yet the 'persistent feeling' that she must become one with it and immerse herself in the stream, recalls the seductiveness of Tennyson's 'Lotus Eaters' and conjures danger: ${ }^{32}$ 'this is the Lotus Land - the green trees stir languorously, sleepily - there is the silver sound of a bird's call'. The rapturous yielding to nature invokes an imagined encounter with the spectral forces of the dispossessed: 'Shall I, looking intently, see vague forms lurking in the shadow staring at me malevolently, wildly, the thief of their birthright? Shall I [...] see a great company moving toward me, their faces averted, wreathed with green garlands, following the little stream in silence until it is sucked into the wide sea ...' $(C W 1,85)$. In these contradictory responses to the untamed landscape, Mansfield shows the modernist preoccupation with what precedes consciousness and what precedes history. This sketch and other passages in her work recall Freud's linking of the unknown or prehistoric to the workings of the unconscious (and his condensation of the two) as in a spatial geological metaphor. ${ }^{33}$ The unconscious exists prior to time and beneath the conscious just as prehistory lies beneath history and knowledge. Like Virginia Woolf, who, as Gillian Beer has shown, was indebted to Darwin's theories of evolution, Mansfield also intuits Darwin's view that history is inextricable from prehistory. But here, as elsewhere in her work (for example, the early story 'Die Einsame' [1904]), her modernist response to these moments of near immersion in the archaic world is one of apprehension about nature's powers: the initial sensation of liberation and exultation is threatened by alienation, fear of engulfment, and perceptions of the spectral and uncanny.

\section{The Sacred Tree and the Arboreal Epiphany}

While flowers in Mansfield's work have powerful symbolic associations and are associated with domesticity, colour and scent, trees have a framing function as architectural features of the landscape. They may symbolise release or escape from human concerns, a signpost of revelation or transformation, but simultaneously a questioning of such liberatory impulses. Hints of pagan beliefs about sacred trees, that they 'could express profound cosmological and spiritual truths' and that minor and major deities lived in individual trees and groves of trees, often underpin these contradictory impressions. ${ }^{34}$ In keeping with the medieval tradition of anima mundi, trees represent imago mundi -- the image of the world - in the form of a giant human being (the trunk is likened to the human body, the branches to arms). Trees with human speech called Ents (from the Anglo Saxon word for giant) appear in Tolkien's epic Lord of the Rings. 35 In 'At the Bay' (1921) an anthropomorphic tree, although not an animated speaking one as in Tolkien's work, displays other human characteristics: 'Then something immense came into view; an enormous shock-headed giant with his arms stretched out. It was the big gum-tree outside Mrs Stubbs's shop' (CW2, 343).

The sacred tree was also valued by pagans as axis mundi (the axis of the world), because, as Carole Cusack points out, it was crucial to their idea of the centre. ${ }^{36}$ The tree that connects the earth to both the underworld below and the heavens above is identified by D. H. Lawrence as representing the might of Pan and a phallocentric tradition: '[it] is a strong-willed, powerful thing-in-itself, reaching up and reaching down $[\ldots]$ it thrusts green hands and huge limbs at the light above and sends huge legs and gripping toes down, down between the trees and rocks, to the earth's middle'. ${ }^{37}$ In the story 'See Saw' (1919), Mansfield presents a feminist reinterpretation of the pagan tradition of the sacred tree and its derivative, the phallic-shaped, upright pillar, as markers of the centre (to tame and make meaningful hostile territory), and she overturns their associations of ritual and the sacred. ${ }^{38}$ As the title 'See-Saw' implies, the tree is both a topographical fulcrum and an axis for diverse human activities. Mansfield's tree is a female version of the archetypal sacred tree,

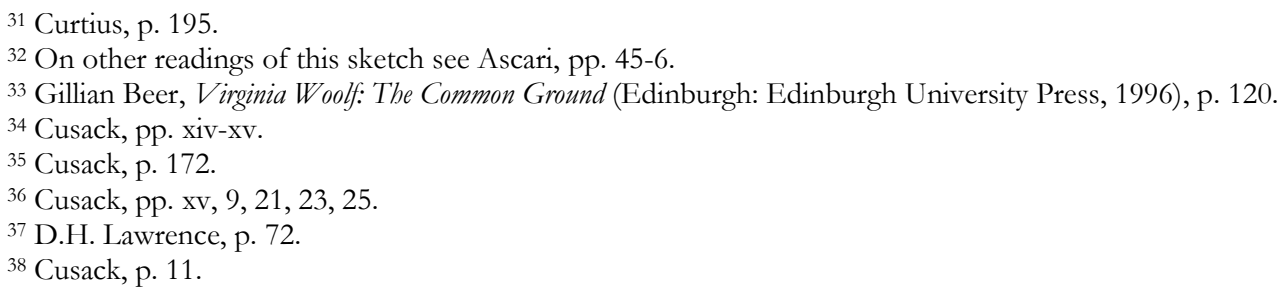


which links the heavenly and underground realms. Positioned next to a small green mound with a bench adjacent, to which all and sundry make their way, it is 'a young chestnut [...] shaped like a mushroom' $(C W 2$, 175) rather than a towering, upright presence. But human beings who visit the tree introduce the mundane and profane, symbolically decentring its pivotal position in the landscape by undermining the connotations of ancient ritual and the sacred: a small boy urinates in the cavern below the tree, and an elderly man waves his hat around to frighten off a bird singing in the tree's branches, saying to his wife, 'Don't want bird muck falling on us' ( $C W 2,177)$.

Gardens, fields, forests and other natural landscapes associated with the locus amoenus constitute pastoral settings for what Josiane Paccaud-Huguet defines as the arboreal epiphany: that is, in the encounter with the natural world the subject's inner forces brim over with plenitude, and are released in a form of jouissance feminine ,a pleasure that transcends the constraints of class and gender. ${ }^{39}$ In 'The Luftbad' (1910), the narrator's fleeting sense of escape from social constructions of who she is and arbitrary identifications imposed on her by other residents of the pension where she is staying in Bad Wörishofen, leads to her communion with sky, tree and cloud. She climbs onto a swing: 'Above, white clouds trailed delicately through the blue sky. From the pine forest streamed a wild perfume, the branches swayed together, sonorously. I felt so light and free and happy - so childish!' (CF1, 177)

In the later story, 'The Escape' (1920), however, the very idea of escape from social and domestic constraints into communion with nature is problematic. Although it begins in an experience of jouissance, escape amounts to no more than an illusion: the paradox of being assailed as well as enlightened makes the experience elude meaningful interpretation. A hen-pecked husband, when he dismounts from the carriage in which he and his wife are travelling, seems to lose himself within the plenitude of nature and find momentary release from the tension caused by her anger towards him. The epiphanic moment is triggered by the sight of an 'immense tree with a round thick silver stem and a great arc of copper leaves that gave back the light and yet were somber'. Like the tree as axis mundi it seems to link the heavens to the earth: 'It seemed to grow, it seemed to expand in the quivering heat until the great carved leaves hid the sky, and yet it was motionless' $(C W 2,221)$. But the voice of a woman floats from within its depths or beyond it - a reminder of the earlier intrusive presence of pagan deities and ancient tree spirits - and disturbs his peace and silence:

Suddenly, as the voice rose, soft, dreaming, gentle, he knew that it would come floating to him from the hidden leaves and his peace was shattered. What was happening to him? Something stirred in his breast. Something dark, something unbearable and dreadful pushed in his bosom, and like a great weed it floated, rocked . . . it was warm, stifling. He tried to struggle, to tear at it, and at the same moment - all was over. Deep, deep, he sank into the silence, staring at the tree and waiting for the voice that came floating, falling, until he felt himself enfolded. (CW2, 221)

Here as elsewhere in Mansfield's work, the promise of the arboreal epiphany - of 'oceanic amplitude' - is compromised by doubt, a fear of immanent submersion, of being overwhelmed. ${ }^{40}$ The epiphanies of stories like 'Bliss' (1918), 'Honeymoon' (1922), and 'Taking the Veil' (1922), also seem to be responses to heightened emotions that fail to offer genuine insight or potential resolution to their underlying causes. More often, as 'In the Botanical Gardens' shows, such enlightened moments of being expose the individual to deeper, uncontrollable powers that threaten to annihilate the experience.

In conclusion, Mansfield's engagement with the classical and medieval traditions of spiritus mundi and anima mundi is indirectly influenced by the representation of Dame Nature as found in the writings of Alan of Lille in her liminal role as intermediary between man and god, helping create order out of chaos while reinvoking paganism and fertility rites. It was undoubtedly directly influenced by Spenser's reinterpretation of the tradition in which the goddess Nature is represented in terms of mutability and change. But it also participates in and contributes to the modernist reshaping of time, space and consciousness. The medieval and renaissance representations of the natural world in which primeval, savage forces existed before the presence of humans and their subjection to and regulation by human clock time, were very attractive to Mansfield and her modernist contemporaries like Woolf and Lawrence. For Mansfield, as with Woolf, the engagement with nature and natural phenomena helps activate changes of consciousness; their epiphanies suggest that being in touch with a spirit of nature or the world (spiritus mundi) enables rejuvenation of the life forces: these belong to prelinguistic states of being that include clouds, sky and waves, elements outside history that have existed from the beginning of time and that show the simultaneity of prehistory in the present moment. Freud talks of traces which precede consciousness and cannot be expressed as that which escapes signification, saying 'There probably exists in the mind of the individual not only what he has experienced himself, but also what he

39 Josiane Paccaud-Huguet, 'A Trickle of Voice: Katherine Mansfield and the Modernist Moment of Being,' in Kimber and Wilson, p. 136.

40 Paccaud-Huguet, p. 136. 
brought with him at birth, fragments of phylogenetic origin, an archaic heritage'. ${ }^{41}$ Both Mansfield and Woolf show such traces of unconscious, archaic memory resurfacing to trouble and disturb the present; Mansfield demonstrates this return in forms of the uncanny and unfamiliar. As with Woolf who used the prehistorical and primeval as a way of overcoming the tyranny of linear narrative, such forces demand her attention not just as indicators of spiritual renewal, but also for their disjunctive potential, This form of defamiliarisation, introducing temporal discontinuity and spatial dislocation, enabled Mansfield to mould and refine her short story technique. Mansfield, Woolf and Lawrence all insist on the untransformed nature of human experience as inevitable in any participation in the natural world, and the translation of their psychological response to this dimension of experience into innovative representational form was a major focus of their modernist endeavour.

\section{Bibliography}

Anon., 'Aims and Ideals', Rhythm 1: 1 (1911), p. 36.

Ascari, Maurizio, 'Katherine Mansfield and the Gardens of the Soul', Katherine Mansfield Studies, 2 (2010), pp. $39-55$.

Beer, Gillian, Virginia Woolf: The Common Ground (Edinburgh: Edinburgh University Press, 1996).

Bergson, Henri, An Introduction to Metaphysics, tr. T. E. Hulme (New York: G.P. Putnam's \& Sons, 1912).

Borlik, Todd A., Ecocriticism and Early Modern English Literature: Green Pastures (London: Routledge, 2011).

Chamberlain, Richard, Radical Spenser: Pastoral, Politics and the New Aestheticism (Edinburgh: Edinburgh University Press, 2005).

Curtius, E. R., European Literature and the Latin Middle Ages, tr. William R. Trask (New York: Harper \& Row, 1963): 106-27.

Cusack, Carole M., The Sacred Tree: Ancient and Medieval Manifestations (Newcastle-upon-Tyne: Cambridge Scholars Publishing, 2011).

Freud, Sigmund, Moses and Monotheism, tr. Katherine Jones. The Internet Library (The Hogarth Press and the Institute of Psychoanalysis, 1939).

https://archive.org/stream/mosesandmonothei032233mbp/mosesandmonothei032233mbp_djvu.txt

[Accessed 1 December 2014].

Goodyear, Frederick, 'The New Thelema', Rhythm 1: 1 (1911), pp. 1-3.

Jackson, Rosemary, Fantasy: The Literature of Subversion (London: Routledge, 1981).

Kaplan, Sydney Janet, Katherine Mansfield and the Origins of Modernist Fiction (Ithaca and London: Cornell University Press, 1991).

Kimber, Gerri and Janet Wilson, eds. Celebrating Katherine Mansfield: A Centenary Volume of Essays (London: Palgrave, 2011).

Kimber, Gerri and Vincent O’Sullivan, eds. The Collected Fiction of Katherine Mansfield 1898-1915, The Edinburgh Edition of the Collected Works of Katherine Mansfield, 2 vols (Edinburgh: Edinburgh University Press, 2012).

Kimber, Gerri and Angela Smith, eds, The Poetry and Critical Writings of Katherine Mansfield, The Edinburgh Edition of the Collected Works of Katherine Mansfield, vol. 3 (Edinburgh: Edinburgh University Press, 2014).

${ }^{41}$ Freud, Moses and Monotheism, tr. Katherine Jones. Internet Archive. (The Hogarth Press and the Institute of Psychoanalysis, 1939): 157. https://archive.org/stream/mosesandmonothei032233mbp/mosesandmonothei032233mbp djvu.txt. Quoted by Beer, Virginia Woolf, 23. 
Lawrence, D. H. 'Remembering Pan', in The Green Studies Reader: From Romanticism to Eco-Criticism, ed. Laurence Coupe (London: Routledge, 2000), pp. 69-71.

Murry, John Middleton, 'Art and Philosophy', Rhythm 1: 1 (1911), pp. 9-12.

Mounic, Anne. “Ah, What is it? - that I Heard”: The Sense of Wonder in Katherine Mansfield's Stories and Poems', in Kimber and Wilson, pp. 144-57.

New, W. H. Reading Mansfield and Metaphors of Form (Montreal \& Kingston, McGill-Queen's University Press, 1999).

O'Sullivan, Vincent and Margaret Scott, eds, The Collected Letters of Katherine Mansfield, 5 vols, (Oxford: Clarendon Press, 1904-2008).

Orton, William, The Last Romantic (London: Cassell \& Co, 1937).

Paccaud-Huguet, Josiane, 'A Trickle of Voice: Katherine Mansfield and the Modernist Moment of Being', in Kimber and Wilson, pp. 131-43.

Park, Katherine. 'Nature in Person: Medieval and Renaissance Allegories and Emblems', in The Moral Authority of Nature, eds Loraine Dalston and Fernando Vidal (Chicago: Chicago University Press, 2003), pp. 50-73.

Woolf, Virginia, Mrs Dalloway (Harmondsworth: Penguin [1925] 1996). 